\title{
EVALUASI RENCANA TATA RUANG WILAYAH (RTRW) BERBASIS CITRA DIGITAL KECAMATAN GEROKGAK KABUPATEN BULELENG TAHUN 2016
}

\section{Gede Eka Wijaya Putra ${ }^{1}$, I Wayan Treman ${ }^{2 *}$}

Prodi Pendidikan Geografi, Universitas Pendidikan Ganesha, Indonesia

\author{
A R T I C L E I N F O \\ Article history: \\ Received 2 April 2018 \\ Received in revised form \\ 6 Agustus 2018 \\ Accepted 12 Agustus 2018 \\ Available online 31 Agustus \\ 2018 \\ Kata Kunci: \\ RTRW \\ Fungsi \\ Kawasan \\ Evaluasi. \\ Keywords: \\ RTRW \\ Area \\ Function \\ Evaluation.
}

\section{A B S T R A C T}

The research was conducted in Gerokgak District with the objectives of: (1) describing land use type in Gerokgak sub district in 2016, (2) knowing the land use accordingly / not appropriate between RTRW and exsisting land condition. The method used analytical descriptive analytic landsat analysis, sampling technique using purposive sampling. Result of research: (1) Land use of Gerokgak subdistrict in $\mathbf{2 0 1 6}$ was obtained seven classes that are forest, mixed garden, fields / fields, rice field, bush / shrub, settlement, water body. (2) Spatial analysis indicates that not all comparable land uses are in accordance with RTRW. Evaluation is obtained from the comparation of RTRW area function with actual land area function. The total area function is $29,232.18 \mathrm{Ha}$ or $74.99 \%$ and does not match $9.751,22 \mathrm{Ha}$ or $25,01 \%$.

\footnotetext{
* Corresponding author.

E-mail addresses: ekawijaya805@gmail.com (Penulis Pertama),wayan ash@yahoo.com (Penulis Kedua)
} 


\section{Pendahuluan}

Penginderaan jauh merupakan ilmu pengetahuan dan seni untuk memperoleh informasi tentang objek, daerah, atau fenomena melalui analisis data yang diperoleh menggunakan piranti tanpa kontak langsung dengan objek, daerah, atau fenomena yang dikaji (Liilesand, et al, 2007 dalam Sutanto 2013). Gagasan bahwa penginderaan jauh merupakan suatu ilmu, bukan sekedar teknologi sudah lama di perdebatkan. Dahlberg dan Jensen (1986) dalam Danoedoro, menyatakan bahwa penginderaan jauh dan kartografi merupakan teknik dalam disiplin ilmu geografi. Gagasan serupa dikemukakan lagi oleh Jensen (2007), yang menyatakan bahwa posisi penginderaan jauh di geografi adalah serupa dengan posisi matematika di ilmu-ilmu alam.

Semakin berkembangnya teknologi penginderaan jauh dan Sistem Informasi Geografis (SIG) dengan berbagai kelebihan yang dimiliki, mendorong orang menggunakan teknik ini untuk studi wilayah. Landsat (Land Satellite) adalah salah satu wahana penginderaan jauh yang diluncurkan pertama kali pada tahun 1972 (Sutanto, 1994). Citra ini memiliki resolusi 30 x 30 meter dan biasanya digunakan dalam penelitian untuk melakukan pantauan terhadap suatu wilayah dalam skala sedang.

Dewasa ini banyak penutup lahan dari suatu wilayah yang dibuka menjadi penggunaan lahan baru oleh akivitas manusia yang semakin beragam untuk memenuhi kebutuhan hidup mereka. Banyaknya penggunaan lahan yang dibuka tidak sesuai dengan kondisi dari lahan itu sendiri atau penggunaan lahan yang belum jelas pemanfaatannya hal ini berdampak terhadap adanya berbagai bencana yang terjadi.

Berdasarkan hasil observasi awal Kecamatan Gerokgak sudah memiliki peta rencana tata ruang wilayah (RTRW) yang merupakan bagian dari rencana tata ruang wilayah kabupaten (RTRWK). Akan tetapi masih terjadi ketidak sesuaian tata guna lahan sehingga perencanaan tidak berjalan dan mengakibatkan masyarakat tetap membuka lahan baru mengikuti keadaan lingkungan disekitarnya.

Pemilihan lokasi penelitian di Kecamatan Gerokgak, terkait dengan bencanabencana yang belakangan melanda Kecamatan Gerokgak. Sehingga perlu dilakukan pengkajian kembali secara eksisting untuk memastikan kawasan mana saja yang tidak sesuai dengan RTRW di Kecamatan Gerokgak.

Permasalahan dalam penelitian ini yaitu: (1) Apa saja jenis penggunan lahan di Kecamatan Gerokgak hasil interpretasi citra landsat pada tahun 2016. (2) Bagaimana Evaluasi kesesuaian Rancangan Tata Ruang Wilayah (RTRW) dengan penggunaan lahan eksisting di Kecamatan Gerokgak. Tujuan dari penelitian ini yaitu: (1) Mendeskripsikan jenis penggunaan lahan di Kecamatan Gerokgak tahun 2016. (2) Mengetahui sejauh mana penggunaan lahan yang sesuai maupun tidak sesuai antara RTRW dengan kondisi lahan secara exsisting.

\section{Metode}

Penelitian ini Dilakukan di Kecamatan Gerokgak, Kabupaten Buleleng, Provinsi Bali. Obyek dalam penelitian ini adalah kesesuaian RTRW dengan penggunaan lahan di Kecamatan Geokgak, memperhatikan obyek penelitian tersebut yang menjadi subyek dalam penelitian ini adalah penggunaan lahan Kecamatan Gerokgak dan peta RTRW 
Kecamatan Gerokgak. Populasi dari penelitian ini adalah seluruh unit penggunaan lahan yang tampak dan dapat dikenali pada citra landsat etm+ daerah Kecamatan Gerokgak. Teknik sampling yang digunakan yaitu purposive sampling yaitu teknik penentuan sampel dengan pertimbangan tertentu (Astawa 2011) pertimbangan yang digunakan adalah keterjangkauan yaitu jalan dengan semua unit lahan terwakili. Teknik analisis yang digunakan adalah deskriptif analitik melalui pendekatan interpretasi citra Landsat ETM+, Ground trouth, dan Sistem Informasi Geografis (SIG).

\section{Hasil dan Pembahasan}

\subsection{Penggunaan Lahan di Kecamatan Gerokgak Hasil Interpretasi Citra Landsat Pada Tahun 2016}

Rencana Tata Ruang Wilayah Kecamatan Gerokgak Tahun 2013-2033 yang dimaksud adalah fokus wilayah yang dikaji yaitu batas administrasi dari Kecamatan Gerokgak saja berdasarkan Rencana Tatar Ruang Wilayah yang selanjutnya disebut RTRW-Kabupaten yang berisi tujuan, kebijakan, strategi penataan ruang wilayah Kabupaten, rencana struktur ruang wilayah Kabupaten, rencana pola ruang wilayah Kabupaten, penetapan kawasan strategis Kabupaten, arahan pemanfaatan ruang wilayah Kabupaten, dan ketentuan pengendalian pemanfaatan ruang wilayah Kabupaten dari Tahun 2013 sampai dengan Tahun 2033 yang meliputi rencana peruntukan ruang untuk fungsi lindung dan rencana peruntukan ruang untuk fungsi budidaya. Kawasan Lindung adalah wilayah yang ditetapkan dengan fungsi utama melindungi kelestarian lingkungan hidup yang mencakup sumber daya alam, sumber daya buatan dan nilai sejarah serta budaya bangsa guna kepentingan pembangunan berkelanjutan.

Kawasan Budidaya adalah wilayah yang dimanfaatkan secara terencana dan terarah sehingga dapat berdaya guna dan berhasil guna bagi kehidupan manusia, terdiri dari kawasan budidaya pertanian dan kawasan budidaya non pertanian. Kawasan hutan lindung yang secara ekologis merupakan satu ekosistem yang terletak pada wilayah kota, kawasan lindung yang memberikan perlindungan terhadap kawasan bawahannya yang terletak di wilayah kota, dan kawasan-kawasan lindung lain yang menurut ketentuan peraturan perundang-undangan pengelolaannya merupakan kewenangan pemerintah daerah kota. Salah satu produk Rencana Tata Ruang Kabupaten adalah Recana Tata Guna Lahan Kabupaten Buleleng Tahun 2013-2033 diperoleh dari Dinas Badan Perencanaan Pembangunan Daerah (BAPPEDA). Hasil analisis Rencana Tata Guna Lahan tahun 2013-2033 di Kecamatan Gerokgak disajikan pada tabel berikut. 
Tabel 1. Luas masing-masing penggunaan lahan berdasarkan RTRW 2013-2033

\begin{tabular}{lcc}
\hline Tata Guna Lahan & \multicolumn{2}{c}{ Tahun 2010-2033 } \\
\cline { 2 - 3 } Hutan Lindung & Ha & $\mathbf{( \% )}$ \\
Hutan Produksi & 16465.971868 & 41,72 \\
Hutan Produksi Tetap & 51.492996 & 0,13 \\
Kawasan Produksi & 4472.420492 & 11,33 \\
Kawasan Pariwisata & 1726.201288 & 4,37 \\
Permukiman & 3704.601034 & 9,38 \\
Perkebunan & 447.880327 & 1,13 \\
Pertanian Tanaman Pangan & 90.289321 & 0,22 \\
Pertanian perkebunan dan Tanaman & 376.967832 & 0,95 \\
Pangan & 3029.613097 & 7,67 \\
TNBB & 9065.258458 & 22,97 \\
TNBB Perairan & 0.319333 & 0 \\
Waduk Gerokgak & 33.262664 & 0,08 \\
\multicolumn{1}{c}{ Jumlah } & & $\mathbf{1 0 0}$ \\
\hline
\end{tabular}

Berdasarkan hasil interpretasi citra landsat ETM+ Kecamatan Gerokgak pada tahun 2016 diperoleh 7 kelas penggunaan lahan yang meliputi hutan, kebun campuran, ladang/tegalan, sawah, semak/belukar, badan air, dan permukiman. Luasan masingmasing penggunaan lahan dapat dilihat pada Tabel 1.

Penggunaan Lahan Kecamatan Gerokgak merupakan hasil dari interpretasi Citra Landsat pada bulan Juli 2016, pemilihan citra ini didasarkan atas pertimbangan tutupan awan sehingga citra pada Bulan Juli 2016 ini dipilih mengingat tutupan awan hanya 4\% dan dapat diasumsikan bahwa citra dapat dipakai. Lillesand dan Kiefer (1987) menyatakan bahwa Interpretasi Citra Landsat ETM+ dilakukan dengan melihat karakteristik dasar masing-masing penggunaan/penutupan lahan pada citra yang dibantu dengan unsur-unsur interpretasi citra. Dalam melakukan interpretasi terlebih dahulu diperlukan adanya klasifikasi penggunaan lahan. Menurut Malingreau (1978), klasifikasi adalah penetapan objek-objek kenampakan atau unit-unit menjadi kumpulankumpulan di dalam suatu sistem pengelompokan yang dibedakan berdasarkan sifat-sifat yang khusus berdasarkan kandungan isinya. Klasifikasi penggunaan lahan merupakan pedoman atau acuan dalam proses interpretasi apabila data pemetaan penggunaan lahan menggunakan Citra penginderaan jauh.

Penelitian sebelumnya yang dilakukan oleh Yunita Lisniawati dan Ariwibowo (2005) menunjukkan bahwa berdasarkan hasil interpretasi citra landsat maka didapatkan kelas-kelas penggunaan lahan pada daerah penelitian dengan luasan yang berbeda-beda antara satu penggunaan lahan dengan yang lainnya. Hasil tersebut menunjukkan bahwa adanya keserasian antara hasil yang diperoleh dengan teori yang dikemukakan pada tinjauan pustaka dan penelitian sebelumnya bahwa dengan melalui metode interpretasi Citra Landsat ETM+ akan diketahui kelas-kelas penggunaan lahan pada suatu wilayah. 
Tabel 2. Penggunaan Lahan Kecamatan Gerokgak Tahun 2016

\begin{tabular}{lcc}
\hline \multicolumn{1}{c}{ Penggunaan Lahan } & \multicolumn{2}{c}{ Tahun2016 } \\
\cline { 2 - 3 } Hutan & Ha & (\%) \\
Kebun Campuran & 23691.705847 & 60,75 \\
Ladang/Tegalan & 5211.106189 & 13,36 \\
Sawah & 2814.925848 & 7,22 \\
Semak/Belukar & 1211.650762 & 3,11 \\
Permukiman & 4990.253414 & 12,79 \\
Badan Air & 637.611391 & 1,64 \\
Jumlah & 440.103393 & 1,13 \\
\hline
\end{tabular}

Evaluasi penggunaan lahan menggunakan analisis spasial tumpang susun (overlay) menghasilkan satu peta yang merupakan gabungan dari peta penyusun kegiatan pemantauan. Dari peta ini dilakukan kegiatan komparasi dengan rencana tata ruang wilayah (RTRW). Sebelumnya data Rencana Tata Ruang Wilayah (RTRW) dan data penggunaan lahan aktual yang diperoleh dilakukan klasifikasi terlebih dahulu menurut fungsi kawasan.

\section{a. Pengertian Fungsi Kawasan}

Kawasan merupakan wilayah yang memiliki fungsi utama lindung atau budidaya (UU Nomor 26 Tahun 2007 tentang Penataan Ruang Bab 1 Ketentuan Umum Pasal 1 point 20,21, dan 22). Kawasan lindung adalah wilayah yang ditetapkan dengan fungsi utama melindungi kelestarian lingkungan hidup yang mencakup sumber daya alam dan sumber daya buatan. Sedangkan kawasan budidaya adalah wilayah yang ditetapkan dengan fungsi untuk dibudidayakan atas dasar kondisi dan potensi sumber daya alam, sumber daya manusia dan sumber daya buatan. Selain kawasan lindung dan kawasan budidaya terdapat pula kawasan penyangga. Kawasan penyangga adalah kawasan yang ditetapkan untuk menopang keberadaan kawasan lindung sehingga fungsi lindungnya tetap terjaga. (Nugraha, dkk 2006) dalam Muryono 2008:9). Kawasan penyangga ini merupakan batas antara kawasan lindung dan kawasan budidaya. Penggunaan lahan yang diperbolehkan hutan tanaman rakyat atau kebun dengan sistem wanatani (agroforestry) dengan pengolahan lahan sangat minim (minimum tillage).

\section{b. Macam-macam Fungsi Kawasan}

Macam Fungsi Kawasan ditetapkan berdasarkan besarnya nilai skor kemampuan lahan dan kriteria khusus lainnya seperti kemiringan lereng, jenis tanah, dan curah hujan. Sebagaimana kriteria dan tata cara yang ditetapkan dalam Buku Petunjuk Penyusunan Pola RLKT (Rehabilitasi Lahan dan Konservasi Tanah). Diklasifikasikan empat fungsi kawasan yaitu Kawasan Lindung (Kode A), Kawasan Penyangga (Kode B), Kawasan Budidaya Tanaman Tahunan (Kode C), Kawasab Budidaya Tanaman Semusim (Kode D). Berdasarkan (SK Menteri Pertanian No. 
837/Kpts/Um/11/1980 dan No.: 683/Kpts/Um/8/1981 tentang kriteria dan tata cara penetapan hutan lindung dan hutan produksi) Berikut ini penjabarannya:

\section{Fungsi Kawasan Lindung (A)}

Fungsi Kawasan Lindung adalah suatu wilayah yang keadaan sumberdaya alam air, flora dan fauna seperti hutan lindung, hutan suaka, hutan wisata, daerah sekitar sumber mata air, alur sungai, dan kawasan lindung lainnya sebagimana diatur dalam Kepres 32 Tahun 1990.

\section{Kawasan Fungsi Penyangga (B)}

Kawasan fungsi penyangga adalah suatu wilayah yang dapat berfungsi lindung dan berfungsi budidaya, letaknya diantara Fungsi Kawasan Lindung dan kawasan fungsi budidaya seperti hutan produksi terbatas, perkebunan (tanaman keras), kebun campur dan lainnya yang sejenis.

\section{Kawasan fungsi Budidaya Tanaman Tahunan (C)}

Kawasan fungsi budidaya tanaman tahunan adalah kawasan budidaya yang diusahakan dengan tanaman tahunan seperti Hutan Produksi Tetap, Hutan Tanaman Industri, Hutan Rakyat, Perkebunan (tanaman keras), dan tanaman buah - buahan.

\section{Kawasan Fungsi Budidaya Tanaman Semusim (D)}

Kawasan fungsi budidaya tanaman semusim adalah kawasan yang mempunyai fungsi budidaya dan diusahakan dengan tanaman semusim terutama tanaman pangan atau untuk pemukiman. Untuk memelihara kelestarian kawasan fungsi budidaya tanaman semusim, pemilihan jenis komoditi harus mempertimbangkan kesesuaian fisik terhadap komoditi yang akan dikembangkan.

Atas dasar pengklasifikasian penggunaan lahan menurut kesesuaian lahan maka dilakukan pengklasifikasian pada masing-masing penggunaan lahan yang diperoleh dari RTRW maupun penggunaan lahan exsisting. Pengklasifikasian penggunaan lahan rencana tata ruang wilayah disajikan pada tabel berikut.

Tabel 3. Fungsi Kawasan Penggunaan Lahan RTRW 2013-2033

\begin{tabular}{ll}
\hline \multicolumn{1}{c}{ RTRW } & \multicolumn{1}{c}{ Fungsi Kawasan } \\
\hline Hutan Lindung & Fungsi Kawasan Lindung \\
Hutan Produksi & Fungsi Kawasan Lindung \\
Hutan Produksi Tetap & Kawasan Fungsi Penyangga \\
Kawasan Produksi & Kawasan Fungsi Budidaya Tanaman Semusim \\
Kawasan Pariwisata & Kawasan Fungsi Budidaya Tanaman Semusim \\
Permukiman & Kawasan Fungsi Budidaya Tanaman Semusim \\
Perkebunan & Kawasan Fungsi Penyangga \\
Pertanian Tanaman Pangan & Kawasan Fungsi Budidaya Tanaman Semusim \\
Pertanian perkebunan dan Tanaman Pangan & Kawasan fungsi Budidaya Tanaman Tahunan \\
TNBB & Fungsi Kawasan Lindung \\
TNBB Perairan & Fungsi Kawasan Lindung \\
Waduk Gerokgak & Fungsi Kawasan Lindung \\
\hline
\end{tabular}

Dari data hasil pengklasifikasian RTRW berdasarkan fungsi kawasan maka diperoleh fungsi kawasan diantaranya fungsi kawasan lindung meliputi hutan lindung, hutan produksi, TNBB, TNBB perairan, dan waduk gerokgak. Fungsi kawasan penyangga 
meliputi hutan produksi tetap, dan perkebunan. Serta kawasan budidaya meliputi Kawasan Produksi Kawasan Pariwisata Permukiman Pertanian Tanaman Pangan Pertanian perkebunan dan Tanaman Pangan.

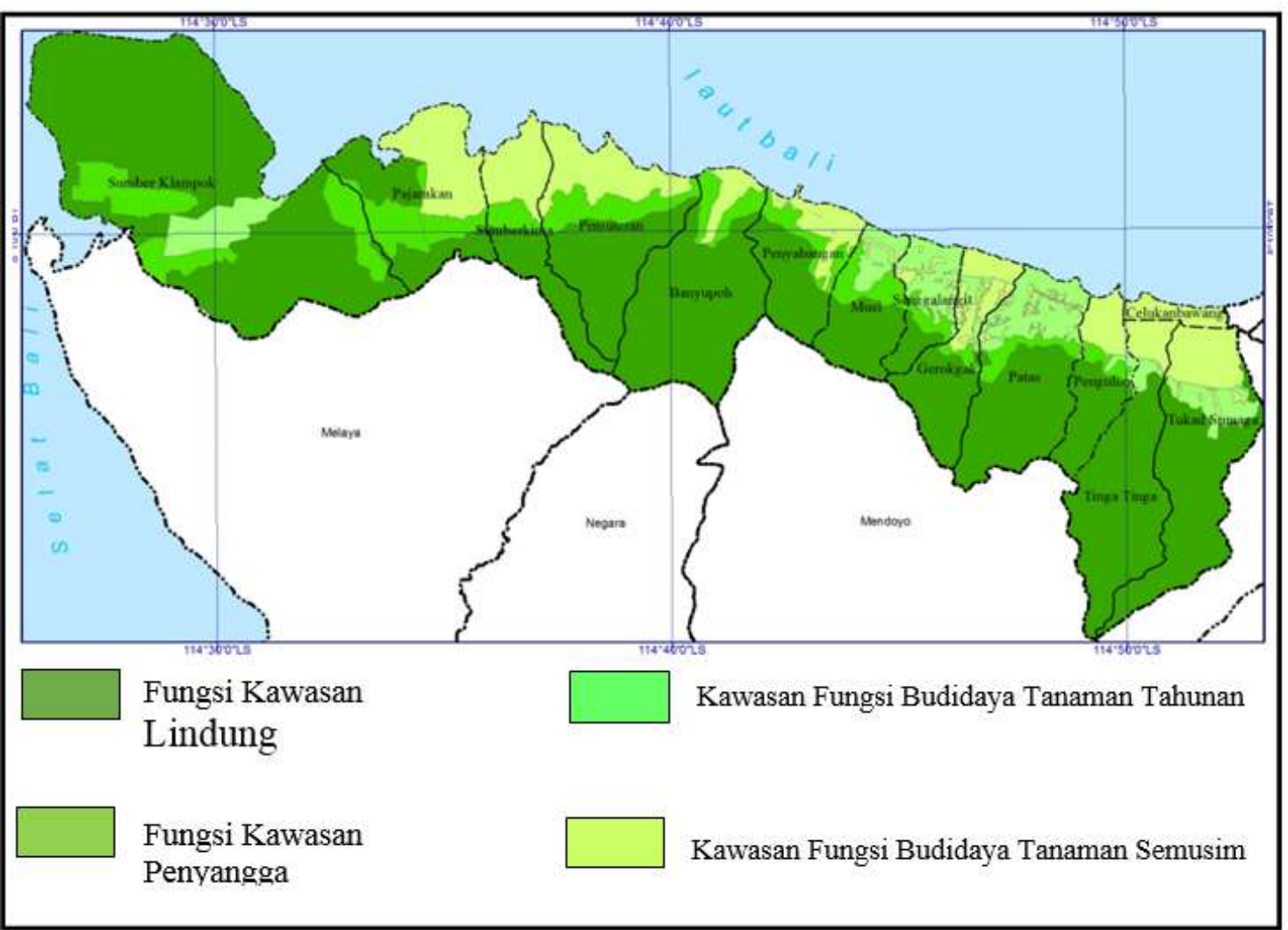

Gambar 1. Peta Fungsi Kawasan

Selanjutnya dilakukan pengklasifikasian yang sama terhadap penggunaan lahan yang diperoleh melalui interpretasi citra. Klasifikasi fungsi kawasan berdasarkan penggunaan lahan aktual disajikan pada Tabel berikut:

Tabel 4. Fungsi Kawasan Penggunaan Lahan Kecamatan Gerokgak Tahun 2016

\begin{tabular}{ll}
\hline \multicolumn{1}{c}{ Penggunaan Lahan } & \multicolumn{1}{c}{ Fungsi Kawasan } \\
\hline Hutan & Fungsi Kawasan Lindung \\
Kebun Campuran & Kawasan Fungsi Penyangga \\
Ladang Tegalan & Kawasan Fungsi Budidaya Tanaman Tahunan \\
Sawah & Kawasan Fungsi Budidaya Tanaman Semusim \\
Semak Belukar & Kawasan Fungsi Penyangga \\
Permukiman & Kawasan Fungsi Budidaya Tanaman Semusim \\
Badan Air & Kawasan Lindung \\
\hline
\end{tabular}

Dari data hasil pengklasifikasian RTRW berdasarkan fungsi kawasan maka diperoleh fungsi kawasan diantaranya fungsi kawasan lindung meliputi hutan lindung, hutan produksi, TNBB, TNBB perairan, dan waduk gerokgak. Fungsi kawasan penyangga 
meliputi hutan produksi tetap, dan perkebunan. Serta kawasan budidaya meliputi Kawasan Produksi Kawasan Pariwisata Permukiman Pertanian Tanaman Pangan Pertanian perkebunan dan Tanaman Pangan. Selanjutnya dilakukan pengklasifikasian yang sama terhadap penggunaan lahan yang diperoleh melalui interpretasi citra. Klasifikasi fungsi kawasan berdasarkan penggunaan lahan aktual disajikan pada tabel berikut.

Tabel 5. Fungsi Kawasan Penggunaan Lahan Kecamatan Gerokgak Tahun 2016

\begin{tabular}{ll}
\hline Penggunaan Lahan & \multicolumn{1}{c}{ Fungsi Kawasan } \\
\hline Hutan & Fungsi Kawasan Lindung \\
Kebun Campuran & Kawasan Fungsi Penyangga \\
Ladang Tegalan & Kawasan Fungsi Budidaya Tanaman Tahunan \\
Sawah & Kawasan Fungsi Budidaya Tanaman Semusim \\
Semak Belukar & Kawasan Fungsi Penyangga \\
Permukiman & Kawasan Fungsi Budidaya Tanaman Semusim \\
Badan Air & Kawasan Lindung \\
\hline
\end{tabular}

Dari pengklasifikasian penggunaan lahan berdasarkan fungsi kawasannya sehingga diperoleh yang termasuk kedalam fungsi kawasan lindung meliputi penggunaan lahan hutan, dan bada, air. Kawasan penyangga meliputi kebun campuran, dan semak belukar. Penggunaan lahan yang termasuk ke dalam kategori fungsi kawasan budidaya meliputi ladang tegalan, sawah, dan permukiman.

Setelah didapatkan klasifikasi dari masing-masing penggunaan lahan berdasarkan fungsi kawasan maka dapat dilakukan proses overlay yang mana pada proses ini overlay meliputi fungsi kawasan. Sehingga dapat diperoleh penggunaan lahan yang terkategori sesuai "S" dan tidak sesuai "TS". Berikut dapat dijabarkan ketidak sesuaian dari fungsi kawasan RTRW dan penggunaan lahan aktual.

Tabel 6. Luas Fungsi Kawasan Sesuai Hasil Komparasi RTRW dan Penggunaan Lahan Aktual

\begin{tabular}{|c|c|c|}
\hline RTRW & PL Aktual & Luas (Ha) \\
\hline Fungsi Kawasan Lindung & Fungsi Kawasan Lindung & 20090.425504 \\
\hline Kawasan Fungsi & Kawasan Fungsi Penyangga & 1616.74996 \\
\hline Kawasan Fungsi Budidaya & Kawasan Fungsi Budidaya & 508.464366 \\
\hline $\begin{array}{l}\text { Tanaman Tahunan } \\
\text { Kawasan Fungsi Budidaya } \\
\text { Tanaman Semusim }\end{array}$ & $\begin{array}{l}\text { Tanaman Tahunan } \\
\text { Kawasan Fungsi Budidaya } \\
\text { Tanaman Semusim }\end{array}$ & 7016.545421 \\
\hline & Total & 29232.1853 \\
\hline
\end{tabular}

Selanjutnya untuk mengidentivikasi fungsi kawasan yang belum sesuai dicari total luas dari masing-masing fungsi kawasan yang tidak sesuai pada data hasil komparasi. Berikut hasil perhitungan luas fungsi kawasan Tidak sesuai. 
Tabel 7. Luas Fungsi Kawasan Tidak Sesuai Hasil Komparasi RTRW Dan Penggunaan Lahan Aktual

\begin{tabular}{|c|c|c|c|}
\hline No & RTRW & PL Aktual & Luas (Ha) \\
\hline (1) & (2) & (3) & (4) \\
\hline 1 & $\begin{array}{l}\text { Kawasan Fungsi Budidaya } \\
\text { Tanaman Tahunan }\end{array}$ & Fungsi Kawasan Lindung & 616.916066 \\
\hline 2 & $\begin{array}{l}\text { Kawasan Fungsi Budidaya } \\
\text { Tanaman Tahunan }\end{array}$ & Kawasan Fungsi Penyangga & 1502.08276 \\
\hline 3 & Fungsi Kawasan Lindung & $\begin{array}{l}\text { Kawasan Fungsi Budidaya } \\
\text { Tanaman Tahunan }\end{array}$ & 824.484355 \\
\hline 4 & Fungsi Kawasan Lindung & Kawasan Fungsi Penyangga & 4071.288336 \\
\hline 5 & Kawasan Fungsi Penyangga & $\begin{array}{l}\text { Kawasan Fungsi Budidaya } \\
\text { Tanaman Tahunan }\end{array}$ & 514.633462 \\
\hline 6 & Kawasan Fungsi Penyangga & $\begin{array}{l}\text { Fungsi Kawasan Lindung } \\
\text { tal }\end{array}$ & $\begin{array}{r}2221.81507 \\
\mathbf{9 7 5 1 . 2 2 0 0 5}\end{array}$ \\
\hline
\end{tabular}

Berdasarkan hasil komparasi funngsi kawasan dapat diperoleh luasan yang terkategorikan tidak sesuai antara Kawasan Fungsi Lindung pada RTRW dengan Kawasan Fungsi Penyangga pada penggunaan lahan aktual dengan luas 4.071,29 Ha dan antara Fungsi Kawasan Penyangga pada RTRW dengan Fungsi Kawasan Lindung pada penggunaan lahan aktual dengan luas 541,6 Ha. Apabila ditambahkan maka total dari Fungsi Kawasan Fungsi Lindung dengan kawasan Kawasan Fungsi Penyangga yang terkategorikan tidak sesuai adalah 4585.922 Ha tercatat mengalami ketidak sesuaian tertinggi.

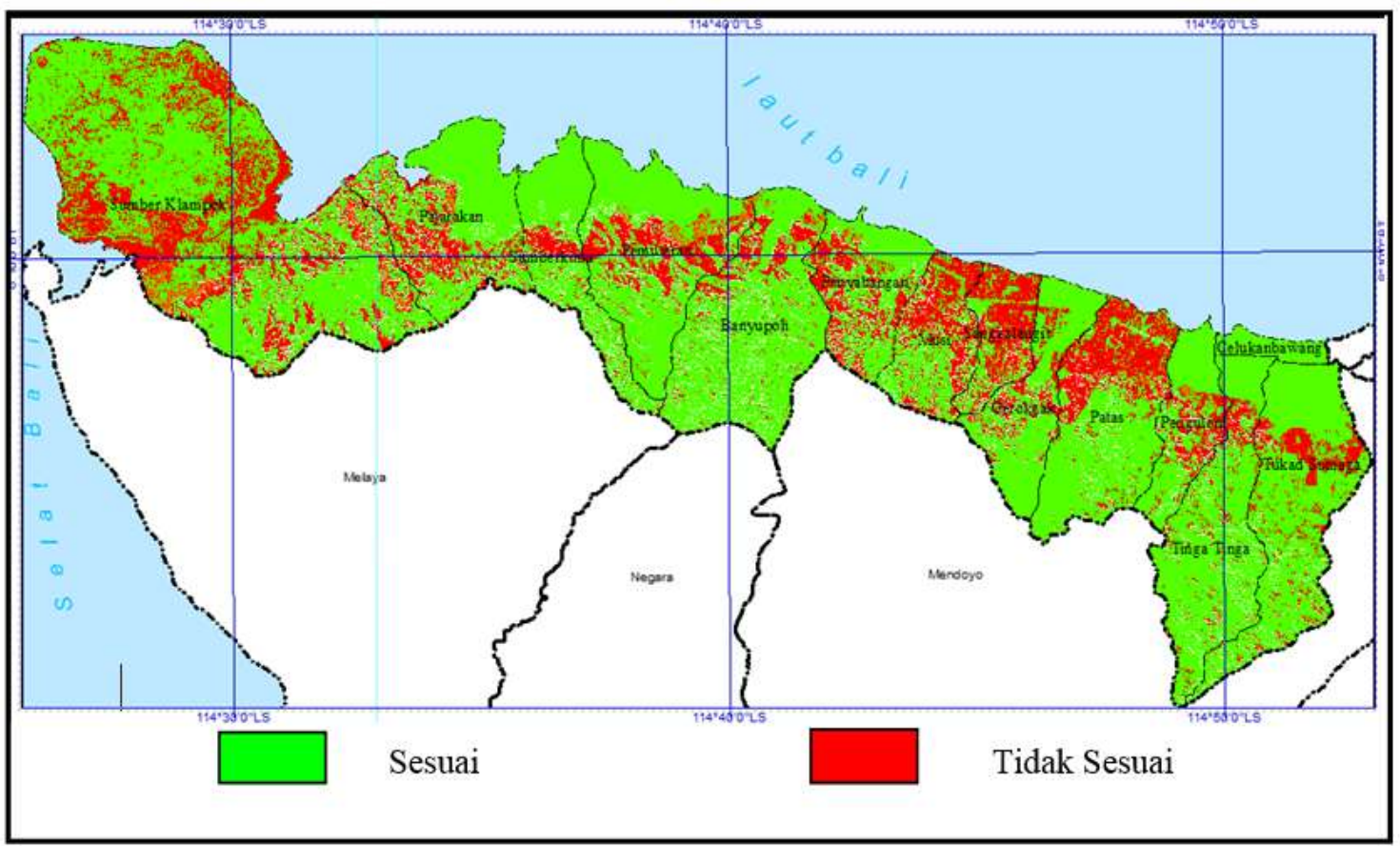

Gambar 2. Fungsi Kawasan Sesuai dan Tidak Sesuai di Kecamatan Gerokgak 
Berdasarkan analisis data evaluasi penggunaan lahan di Kecamatan Gerokgak. Didapatkan hasil evaluasi yang mendominasi adalah kawasan sesuai (S) dengan luas $29232.1853 \mathrm{Ha}$ atau 74,99\%, dan kawasan tidak sesuai (TS) 9751.22005 Ha atau 25,01\%. Evaluasi penggunaan lahan di Kecamatan Gerokgak dapat disajikan pada Tabel berikut.

Tabel 8. Evaluasi Penggunaan Lahan di Kecamatan Gerokgak 2016

\begin{tabular}{ccc}
\hline Evaluasi & Luas & Persentase (\%) \\
\hline Sesuai & 29232.1853 & 74.99 \\
Tidak Sesuai & 9751.22005 & 25.01 \\
Total & $\mathbf{3 8 9 8 3 . 4 0 5 4}$ & $\mathbf{1 0 0}$ \\
\hline
\end{tabular}

\subsection{Evaluasi penggunaan lahan sesuai dengan Rancangan Tata Ruang Wilayah (RTRW) di Kecamatan Gerokgak}

Berdasarkan pengolahan data yang dilakukan maka diketahui hasil luasan masing-masing kondisi penggunaan lahan yang dapat diamati pada tabel 4.16. Dari tabel tersebut dapat diketahui bahwa antara penggunaan lahan di Kecamatan Gerokgak dengan RTRW Kecamatan Gerokgak sudah terjadi penyimpangan di beberapa wilayah.

Hasil dari evaluasi rencana tata ruang wilayah (RTRW) Kecamatan Gerokgak dilakukan dengan menggunakan Citra Landsat ETM+ menujukkan adanya indikasi penggunaan lahan tidak sesuai. Penggunaan lahan yang terkategori tidak sesuai di ketahui dari adanya penyimpangan antara fungsi kawasan RTRW dengan fungsi kawasan secara aktual. Data menunjukkan adanya penyimpangan antara fungsi kawasan budidaya tahunan dengan fungsi kawasan penyangga dan paling banyak terjadi di desa Musi, Sanggalangit, Gerokgak, dan Patas. Dilanjutkan dengan fungsi kawasan budidaya tahunan mengalami penyimpangan terhadap fungsi kawasan lindung, fenomena ini terjadi di desa Pemuteran, Tinga-tinga, dan Tukadsumaga. Dan fungsi kawasan yang paling banyak mengalami ketidak sesuaian adalah kawasan yang rentan adanya penyimpangan yakni antara fungsi kawasan lindung dengan fungsi kawasan penyangga disamping kawasan ini berbatasan langsung lokasi dari masing-masing fungsi kawasan berada jauh dari pantauan sehingga kurang adanya control dari pihak terkait yang menangani permasalahan tersebut.

Faktor yang paling berpengaruh dalam hal ini tentu berkaitan dengan kebutuhan dari masyarakat sehingga mereka cendrung memilih daerah itu sebagai tempat mereka beraktivitas dan imbasnya terhadap penggunaan lahan. Contohnya penggunaan lahan permukiman, Daerah Celukanbawang merupakan tempat industry terbukti dengan adanya pelabuhan dan pabrik yang menarik masyarakat untuk membangun permukiman mengingat banyaknya tempat bekerja, sehingga permukiman banyak di temui di daerah tersebut. Kemudian ada kawasan yang diperuntukkan sebagai penggunaan lahan perkebunan dengan daerah sebaran paling luas di Desa Tukadsumaga berkenaan dengan hal tersebut Desa Tukadsumaga memiliki komoditi tanaman jeruk yang biasanya cocok apabila ditanam dilahan yang karakteristiknya sama dengan tegalan yang mana lahan tegalan banyak di jumpai di Desa Sumberkelampok. 
Tanaman pangan biasanya terdiri dari tanaman yang bersifat pokok seperti beras, dan jagung yang tentu memerlukan pengairan yang cukup hal inilah yang menyebabkan sebagian besar penggunaan lahan tanaman pangan banyak di temui di Desa Tukadsumaga. Pertanian tanaman perkebunan \& hortikultura yang tersebar di hampir semua desa disebabkan karena lahan yang ada di kecamatan gerokgak cukup baik ditanami tanaman hortikultura seperti cabai, jeruk, anggur, dan beberapa tanaman lainnya yang dapat ditemui di Kecamatan Gerokgak.

Berdasarkan hasil dari analisis penggunaan lahan yang terkategorikan tidak sesuai dimana terdapat beberapa fungsi kawasan yang mengalami penyimpangan seperti diantaranya kawasan fungsi budaya tahunan yang mengalami penyimpangan dengan fungsi kawasan lindung dengan luas $1441.4 \mathrm{Ha}$, kawasan fungsi budaya tahunan dengan fungsi kawasan penyangga dengan luas $2016.716 \mathrm{Ha}$, fungsi kawasan penyangga dengan fungsi kawasan lindung yang mengalami penyimpangan terluas yakni mencapai 6293 Ha. Adapun data ketidak sesuaian fungsi kawasan disajikan pada tabel berikut.

Tabel 9. ketidak sesuaian fungsi kawasan RTRW dan Penggunaan lahan aktual

\begin{tabular}{clc}
\hline NO & \multicolumn{1}{c}{ Fungsi Kawasan } & Luas \\
\hline $\mathbf{1}$ & $\begin{array}{l}\text { Kawasan Fungsi Budidaya } \\
\text { Tanaman Tahunan dengan } \\
\text { fungsi kawasan lindung }\end{array}$ & 1441.4 \\
\hline $\mathbf{2}$ & $\begin{array}{l}\text { Kawasan Fungsi Budidaya } \\
\text { Tanaman Tahunan dengan } \\
\text { fungsi kawasan Penyangga }\end{array}$ & 2016.716 \\
\hline $\mathbf{3}$ & $\begin{array}{l}\text { Fungsi kawasan lindung } \\
\text { dengan fungsi kawasan } \\
\text { penyangga }\end{array}$ & 6293.103 \\
\hline & Total & 9751.219 \\
\hline
\end{tabular}

Dari penyajian data tabel diatas dapat penggunaan lahan yang termasuk kedalam fungsi kawasan dan mengalami ketidak sesuaian antara fungsi kawasan pada RTRW dan fungsi kawasan berdasarkan penggunaan lahan aktual. Sehingga dari data inilah peneliti jadikan sebagai bahan evaluasi atau rekomendasi terhadap rencana tata ruang wilayah (RTRW) yang telah ditetapkan, mengingat dengan adanya penelitian ini dapat diketahui beberapa penggunaan lahan yang belum sesuai dengan perencanaan yang telah dibuat sebagai dasar dalam pembangunan berkelanjutan. Adapun peta evaluasi rencana tata ruang (RTRW) berbasis citra digital dapat disajikan pada gambar sebagai berikut.

\section{Simpulan dan Saran}

Terdapat tujuh tipe penggunaan lahan utama di Kecamatan Gerokgak yaitu: Hutan, Kebun Campuran, Ladang/tegalan, Sawah, Semak/belukar, Permukiman, dan Badan Air. Tingkat keakuratan interpretasi citra berdasarkan uji validasi menunjukkan bahwa pengolahan data yang dilakukan mengacu pada hasil interpretasi yang memiliki tingkat akurasi $87,72 \%$, dengan batasan tingkat kepercayaan sebesar $85 \%$. Berdasarkan proses 
overlay dua data penggunaan lahan yaitu penggunaan lahan aktual (eksisting) dengan rencana tata ruang wilayah kabupaten (RTRWK) yang berfokus kepada daerah administrasi Kecamatan Gerokgak. Diperoleh penggunaan lahan berdasarkan fungsi kawasan di Kecamatan Gerokgak yaitu Sesuai (S), dan Tidak Sesuai (TS). Pada kategori Sesuai (S) terdapat 29.232.1853 Ha atau 74,99\%, dan Tidak Sesuai (TS) 9751.22005 atau 25,01\%. Dari masing-masing kategori memiliki karakteristik tersendiri dan yang sesuai untuk dijadikan sebagai bahan evaluasi yaitu pada kategori tidak sesuai (TS). Sehingga diperoleh evaluasi rencana tata ruang wilayah (RTRW) antara lain, Kawasan Fungsi Budidaya Tanaman Tahunan dengan fungsi kawasan lindung, Kawasan Fungsi Budidaya Tanaman Tahunan dengan fungsi kawasan Penyangga, Fungsi kawasan lindung dengan fungsi kawasan penyangga.

Perlu dilakukan penelitian sejenis di setiap tahunnya mengingat semakin maraknya fenomena alih fungsi lahan Penggunaan lahan yang paling tinggi mengalami ketidak sesuaian yaitu Pertanian Perkebunan dan Hortikultura, ini menandakan terjadi alihfungsi lahan pertanian terutama pada sector buah-buahan sudah tidak sesuai dengan perencanaan sehingga akan mengganggu pembangunan berkelanjutan. Fenomena ini tentu menjadi bahan evaluasi pemerintah daerah yang terkait dalam pengambilan keputuasn dan kebijakan-kebijakan pengembangan wilayah. Keakuratan hasil interpretasi citra dengan menggunakan metode supervised classification pada keempat titik tahun belum mencapai $100 \%$. Disarankan peneliti agar lebih teliti dalam menentukan training area agar didapatkan hasil yang maksimal mendekati nilai kebenaran 100\%. Perlu dilakukan perbandingan dan peninjauan ulang database Penggunaan Lahan Kecamatan Gerokgak. Untuk meningkatkan kualitas data dalam analisis selanjutnya, diharapkan dari lembagalembaga pengguna untuk melakukan pengadaan data (citra) terbaru.

\section{Daftar Rujukan}

Astawa, Ida Bagus Made. 2011. Atatistika Terapan untuk penelitian. Buku Ajar (tidak diterbitkan). Singaraja Undiksha.

Danoedoro, Projo. 2012. Pengantar Penginderaan Jauh. Yogyakarta: C.V ANDI Offset

Lisnawati, Yunita dan Ari Wibowo. 2007. "Penggunaan Citra Landsat ETM+ Untuk Monitoring Perubahan Penggunaan Lahan Di Kawasan Puncak", Volume 4, Nomor 2 (hlm.069-118)

Malingreau. 1978. Penggunaan Lahan Pedesaan Penafsiran Citra Untuk Interpretasi dan Analisisnya. Yogyakarta: Pusat Pendidikan Interpretasi Citra

Sutanto. 1986. Penginderaan Jauh Jilid I. Yogyakarta: Gadjah Mada University Press. 1994. Penginderaan Jauh Jilid 2. Yogyakarta: Gadjah Mada University Press.

-------- . 2013. Metode Penelitian Penginderaan Jauh. Yogyakarta: Ombak 